\title{
BETWEEN BULLYING AND OTHER VIOLENCES: EXPLORING THE SCHOOL EXPERIENCES OF IMMIGRANT AND REFUGEE CHILDREN AT ELEMENTARY SCHOOL IN DUQUE DE CAXIAS (RJ)
}

\author{
CAMila CALDeira LANGFeldT \\ MARIT URSIN \\ Norwegian University of Science and Technology (NTNU), Trondheim, Norway
}

\begin{abstract}
This article explores the main challenges faced by a small group of children from Angola and from the Democratic Republic of Congo in two elementary schools in Duque de Caxias, a municipality part of the Metropolitan Region of Rio de Janeiro. The article draws from a qualitative multi-method study conducted with children and community members. The empirical material shows that most of the Angolan and Congolese participants of this study suffer different types of peer harassment in school, as bullying and peer coercion. Moreover, the participants experience a triple kind of discrimination in school, first because they are black, second because they are outsiders, and third because they have an African background.
\end{abstract}

KeYwords: Child Research. Formal Education. Refugee and Immigrant Children. Refugee Education.

\section{INTRODUCTION}

Brazil receives refugees seeking asylum on a daily basis, and it is part of the country's response to offer access to formal education for immigrant and refugee children' in the national territory (UNESCO, 2019; UNICEF, 2019). The 2030 Agenda for Sustainable Development, through the Sustainable Development Goal 4: Education for all (UNESCO, 2016), states that vulnerable groups, such as immigrants and refugees, should receive particular attention from the educational offices. Furthermore, immigrant and refugee children must be included in the national educational systems, this is an international obligation (UNESCO, 2019; UNHCR, 2019; UNICEF, 2019).

Due to the work of public offices and despite many difficulties, children are accessing national schools on equal terms with the Brazilian population. However, Brazil does not have any specific educational policy for immigrant and refugee children. Regarding the challenges that this group face at school, DRYDEN-PETERSON (2016) and SIDHU; TAYLOR e CHRISTIE (2011) observed that language, the kind of pedagogy used, separated classes, and discrimination are some of the main problems. However, each country has its educational system with own specificities, therefore the challenges for the inclusion of immigrant and refugee children in the national systems vary.

The Brazilian public educational system faces several challenges, such as educational inequalities, lack of investment, devaluation of public education, 
devaluation and underpayment of teachers and educational professionals. At the local level, schools have to cope with infrastructure problems; the shortage of school supplies; a lack of classrooms; and low quantity of teachers and other school employees. In this way, the presence of immigrant and refugee students come on top of teachers' heavy workload, and the students may experience a wide range of difficulties.

This article is based on a master's study at the master's program in Childhood Studies at the Norwegian University of Science and Technology (NTNU) ${ }^{2}$. The study aimed to increase the knowledge about immigrant and refugee children schooling experiences in Brazil, taking children's experiences as the main empirical data. The fieldwork was conducted in two elementary schools in Duque de Caxias, a municipality part of the Metropolitan Region of Rio de Janeiro.

Following, the article is divided in four parts. After this introduction, the next section contextualizes, briefly, refugees in Brazil and the school access to immigrant and refugee children. Following, the theoretical framework of this study is presented: the interdisciplinary field of childhood studies, the study field, the participants, and the methods. Following next, the findings are discussed divided into four sections and the final reflections are presented.

A BRIEF CONTEXTUALIZATION OF REFUGEES AND THEIR ACCESS TO FORMAL EDUCATION IN BRAZIL

In December 2018, Brazil had 11.231 recognized refugees, and 161.057 requests for recognition of the refugee condition being assessed (CONARE, 2019). The number of recognized refugees in Brazil is increasing. While in 2011 there were 4.035 refugees, in 2018 the country recognized 11.231 people. In total, the biggest group is from Syria (40\%), followed by people from the Democratic Republic of Congo (14\%), Angola (9\%), Colombia (7\%), and Venezuela (3\%). Other nationalities comprise $30 \%$ of the refugees in Brazil (CONARE, 2019). However, the economic crisis in Venezuela is leading to an increasing number of families and children to seek asylum in Brazil every day.

Regarding the situation on the northern Brazilian border, UNICEF (2020) highlighted that 9.583 refugee children are in very vulnerable conditions. In 2019 the Federal Public Defenders (DPU) in the city of Pacaraima attended a total of 6.085 children and adolescents that were considered in a "particular migration difficulty" (DPU, 2020). That means that the children were either separated from their legal guardians, completely unaccompanied by an adult, or undocumented. During only the second semester of 2019, 423 children had entered Brazil alone (DPU, 2020). Moreover, during the same period, 1.998 children entered without their legal guardians, and 1.080 children were undocumented. Of those, 52,7\% were boys, 47,3\% girls, and 9,75\% were indigenous children ${ }^{3}$. Most of the children in a particular migration difficulty were between 13 to 17 years old, followed by the group from zero to six years old, and by the group from seven to 12 years old (DPU, 2020).

Regarding the school access for immigrant and refugee children, any child can be enrolled at school in Brazil based on the 1988 Federal Constitution. Moreover, the Brazilian Statute of Children and the Adolescent (BRASIL, 1990), the Act of Guidelines 
LANGFELDT, C. C.; URSIN, M.

and Bases of National Education (BRASIL, 1996), the National Plan of Education (BRASIL, 2014); and the Brazilian Migration Law (BRASIL, 2017) establish the equal access to education for all children regardless of nationality. However, there is an absence of federal legislation concerning immigrant and refugee education. Thus, States educational offices have been tackling the situation almost alone. The few orientation documents that exist were produced by the States of São Paulo ${ }^{4}$, Paraná5, and the Federal District ${ }^{6}$. São Paulo has also produced two booklets on immigrant and refugees' enrollments and integration for school staffs (GOVERNO DO ESTADO DE SÃO PAULO, 2018a; b).

According to the above-mentioned documents, children's enrollment in school can be made with any one of the following documents: the National Registry of Foreigners (RNE), the Provisional Document of National Migration Registry, the Provisional Foreigner Identity Document (Federal Police Protocol), passport, birth certificate issued by the country of origin (translated or not), and the school documents issued by the country of origin (translated or not). Enrolment cannot be denied in case of the absence of identification documents. However, the situation is not simple. Many institutions do not know about this regulation, and migrants and refugees still face challenges with children's enrollment as it was mentioned to us by a representative of DPU. The Public Prosecutor's Office has documented (MINISTÉRIO PÚBLICO FEDERAL, 2017) that Venezuelan refugees have difficulties enrolling their children in Brazilian public schools because of the lack of translated documents.

In connection with the school documents, it is also not obligatory to submit any documentation to prove the previous education as a requirement for enrollment. Furthermore, is not necessary to have a certified translation of the previous schooling documentation. In case of the absence of documentation, the school management must realize a classification procedure. If it is not possible to classify the student as soon as possible, or if there are other obstacles, the child should be enrolled with the same age group, and the reclassification can occur any time during the school year (GOVERNO DO ESTADO DE SÃO PAULO, 2018b). After school admission, no special education policy exists. Children are enrolled in a standard classroom with the same curriculum as Brazilian children. Following, the next section presents the theoretical and methodological ground where this study is situated.

\section{CHILDHOOD STUDIES}

This study is rooted in the interdisciplinary field of childhood studies. One of the core features of this field is that children are social actors that uniquely experience the world, so child-focused research is "conducted with children as the subjects, rather than the objects of the research" (JAMES; JAMES, 2012, p. 10). Empirical studies in childhood studies field take children's experience and knowledge as the main empirical data (JAMES; JENKS; PROUT, 1998; MAYALL, 2005; MORROW, 2013; PUNCH, 2016). In addition, ABEBE (2009), referring to ENNEW e PLATEAU (2004), highlights that "participatory approaches do not solely rely on children by ignoring adults. Instead, they take children and their views seriously while simultaneously giving everyone who has a stake (in childhood) a voice and a choice about what is being researched" (ABEBE, 2009, p. 452). 
In this way, the study that generated the data for this article was inspired by children's rights 'to be properly researched' (ENNEW ET AL, 2009). This right is based on the interpretation of articles 3.3, 12.1, 13.1, and 36 (ENNEW ET AL, 2009, p. 1:22) of the United Nations Convention on the Rights of Child - UNCRC (United Nations, 1989). The interpretation of these rights for child research implies that: the project must be conducted in conformity with high scientific standards; that children perspectives and knowledge are integral to the study, as well as the other adult participants; that the methods used are designed and redesigned to help children to express themselves in the best possible way; that the study has an ethical methodology; and that the participants are not exploited, prejudiced, or harmed in any stage of the research process, which also means that confidentiality and anonymity of the research participants must be a fundamental aspect of the project. Following, the study field, the participants and the methods used are briefly presented.

\section{STUDY FIELD, PARTICIPANTS AND METHODS}

This study was developed at two elementary schools, one elementary I and one elementary II, in an impoverished region of Duque de Caxias. According to the Political Pedagogical Plan (PPP) from one of the schools, most of the students live in the community around the school, where a large part of the population lives under a very precarious life situation, including cases of begging. Many members of children's families are unemployed or underemployed, living on social programs, such as Bolsa Família. The document also highlights that many students stop studying at a young age in order to contribute to the family income, and that many students emancipate themselves to assume responsibilities within the household. Moreover, it is highlighted that there are places that sell toxic substances around the school, and there is a large group of young people involved with licit and illicit types of drugs. Regarding violence, Duque de Caxias had the highest homicide rate for young blacks and brown (pardos) in the Metropolitan Region of Rio de Janeiro in 2010 (CASA FLUMINENSE, 2010).

Of the children that participated in this study, four are refugees from the Democratic Republic of Congo and two are immigrants from Angola. The families from Congo have been in Brazil for more than 10 years. The youngest child was born in Brazil. Of the children from Angola, one family has been in Brazil for an extended period and the other child has been in Brazil for two years. The following table presents the participants. All children received pseudonyms. 
LANGFELDT, C. C.; URSIN, M.

Table 1 - Participant children divided by gender, country, status, age, and grade.

\begin{tabular}{|cccccc|}
\hline Pseudonym & Gender & Country & Status & Age & Grade \\
\hline Xitu & Male & Angola & Immigrant & 18 & $9^{\text {th }}$ \\
Chó & Female & Angola & Immigrant & 10 & $4^{\text {th }}$ \\
Kyra & Female & Democratic Republic of the Congo & Refugee & 12 & $7^{\text {th }}$ \\
Mole & Male & Democratic Republic of the Congo & Refugee & 10 & $4^{\text {th }}$ \\
Sun & Female & Democratic Republic of the Congo & Refugee & 11 & $4^{\text {th }}$ \\
Ya & Female & Democratic Republic of the Congo & Refugee & 8 & $2^{\text {th }}$ \\
\hline
\end{tabular}

Source: The authors (2019).

Children partook in this study through focus-group discussions, semi-structured interviews, a collective draw activity, a sentence completion activity, and registers in diaries. In addition, we made unstructured observations in both schools. At the sentence completion activity, children were asked to fill in a form with 16 questions. Following are the questions:

Table 2 - Sentence completion questions elaborated to the study.

1. What the school represents for me;

2. The best of the school is;

3. The worst thing about school is;

4. At school, I feel happy when;

5. At school, I feel sad when;

6. At school, I feel angry when;

7. I like school because;

8. I don't like school because;
9. My biggest challenge in school is;

10. My relationship with my classmates is;

11. My relationship with my teachers is;

12. If I could change something at school, I would change...;

13. The place I live is;

14. My house is;

15. My family is;

16. I would like the adults to know that...

Source: The authors (2019).

All the activities were developed and conducted inside the children's schools. As for the adult participants, three pedagogical advisers, an immigrant mother and an employee from the Duque de Caxias Secretary of education partook in the study. The adult participants joined the study through semi-structured interviews and a semistructured group interview (KVALE AND BRINKMANN, 2009).

The field study took place over a period of two months. From the proposed activities, the participant observation, listening to the children, the interviews with the adults and the data produced by a partner research group ${ }^{8}$, we are able to say that the main challenge face by this small group of children in those schools is the peer relationships. The participants reported experiencing bullying, racism, xenophobia, and peer coercion in their everyday life at school. The following sections will address each one of these issues. 


\title{
BULLYING
}

We observed a culture of bullying at both schools, where all children, including the Brazilian, suffer from it. During fieldwork, children were teasing each other almost constantly, many children were called by strongly offensive nicknames, and for some of them, bullying was an intermittent situation. According to the Revised Olweus Bully/Victim Questionnaire, a student is suffering from bullying when other students

\begin{abstract}
1. say mean and hurtful things or make fun of him or her or call him or her mean and hurtful names; 2 . completely ignore or exclude him or her from their group of friends or leave him or her out of things on purpose; 3. hit, kick, push, shove around, or lock him or her inside a room; 4. tell lies or spread false rumors about him or her or send mean notes and try to make other students dislike him or her; 5. and do other hurtful things like that. (OLWEUS, 2001, p. 6)
\end{abstract}

However, to have these actions understood as bullying, those practices need to happen repeatedly over time and the student being bullied should have difficulties defending himself or herself. Thus, this exact practice was noticed form the very first unstructured observations in the field. Moreover, Angolan and Congolese children shared many experiences of episodes of bullying with us. The next table presents some of Angolan and Congolese children writings about bad peer relationships and bullying at school.

Table 3 - Bullying described by the Angolan and Congolese children.

\begin{tabular}{|c|c|}
\hline \multicolumn{2}{|r|}{ Mole } \\
\hline 3. O pior da escola é: & 3. The worst thing about school is: boring students. \\
\hline Dumo. shotas. & 5. At school, I feel sad when: some students threaten me \\
\hline 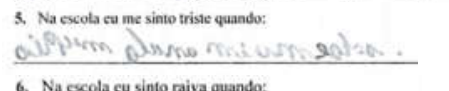 & $\begin{array}{l}\text { 6. At school, I feel angry when: (students) make fun of } \\
\text { me. }\end{array}$ \\
\hline In: foorm. & 8. I don't like school because: there are troublemaker \\
\hline 8. Eu nầ gosso da escola porque: & students. \\
\hline 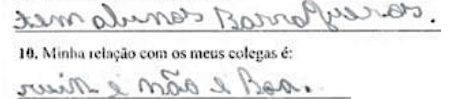 & $\begin{array}{l}\text { 10. My relationship with my classmates is: bad and not } \\
\text { good. }\end{array}$ \\
\hline 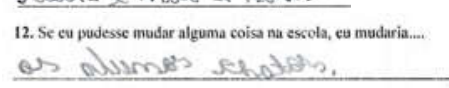 & $\begin{array}{l}\text { 12. If I could change something at school, I would } \\
\text { change: the boring students. }\end{array}$ \\
\hline
\end{tabular}

Inter-Ação, Goiânia, v.46, n.2, p. 624-644, maio/ago. 2021. Disponível em: <http://dx.doi.org/10.5216/ia.v46i2.67833>. 
LANGFELDT, C. C.; URSIN, M.

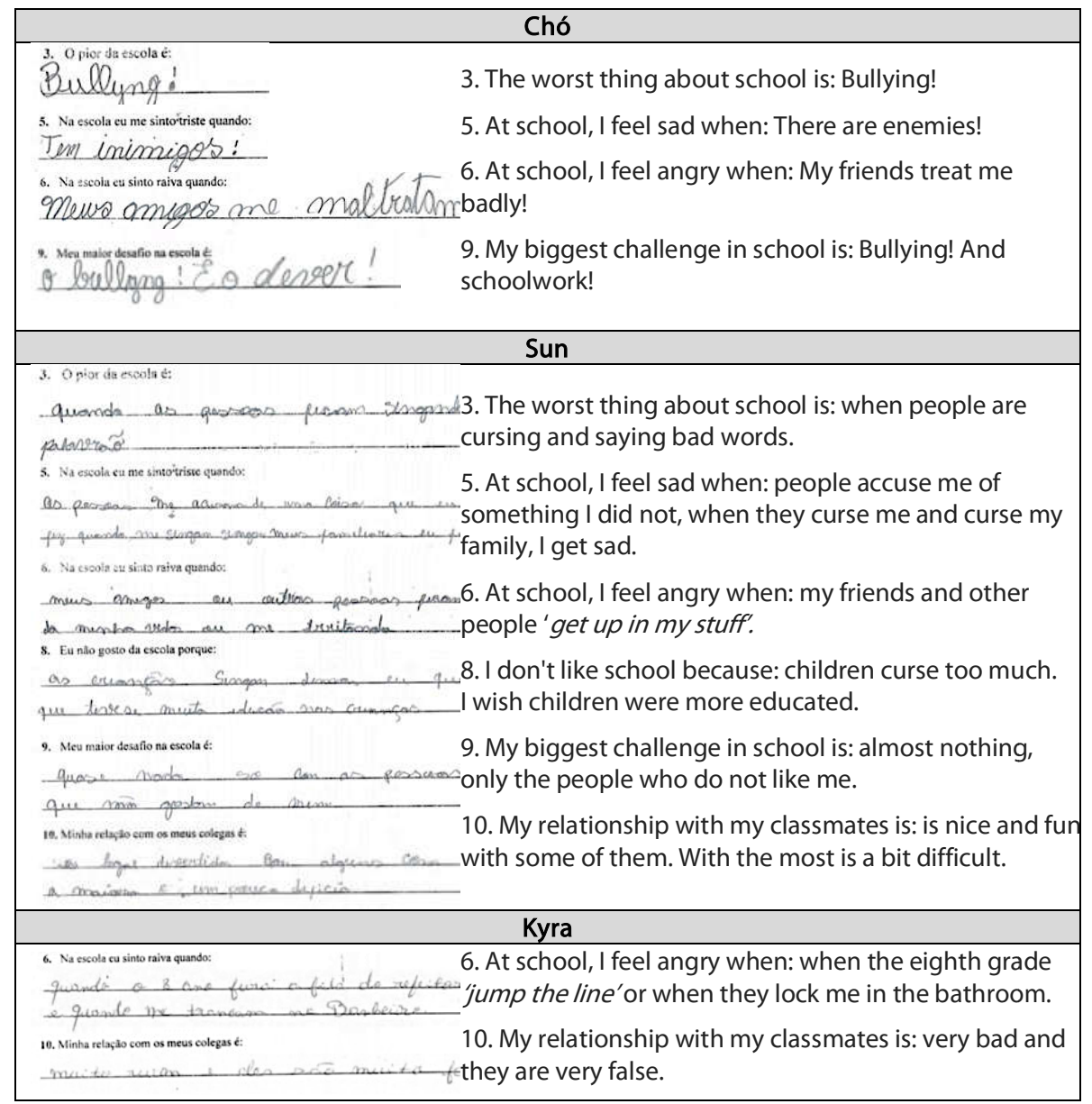

Source: The authors (2019).

Although the answers, the severity of the complains, the challenges faced by children go beyond bullying. Peer harassment researchers "have repeatedly found racial/ethnic disparities in bullying" (Peguero, 2019, p. 159), showing that "of the many diverse sociocultural factors and inequalities associated with the stratification of bullying is race/ethnicity" (Peguero, 2019, p. 159). Moreover, refugee education studies have extensively described that immigrant and refugee children face race and ethnic discrimination in formal education worldwide. (BROWN, 2015; CORREA-VELEZ; GIFFORD; BARNETT, 2010; DRYDEN-PETERSON, 2015; 2016; GRAHAM; MINHAS; PAXTON, 2016; PEGUERO, 2009). This same pattern was also found in this study. Beyond bullying, Angolan and Congolese children experience racism and xenophobia inside the schools. The next section presents children's experiences with racism. 


\section{RACISM}

Kyra is the child who spoke the most about harassment in this study. The experience of being harassed and discriminated has been a constant in her life since she started attending school in Brazil. During the semi-structured interview, Kyra mentioned that "in my old school, it was the same as here: bullying [...] nobody liked me there either". She affirmed that in her other school, her classmates isolated her, and told others to isolate her as well. "So, every person who was coming was isolating me". Moreover, when she changed schools, she "was expecting it to be different, but it is the same thing here". Kyra recognizes that she suffers not only bullying:

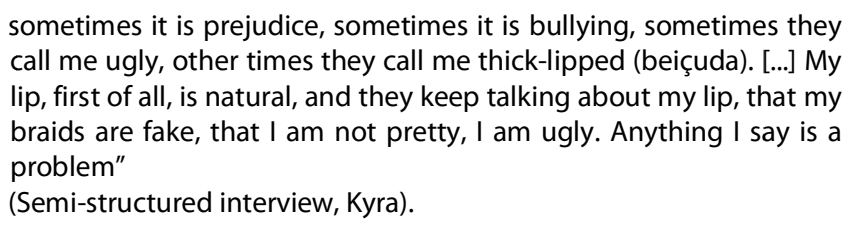
call me ugly, other times they call me thick-lipped (beiçuda). [...] My lip, first of all, is natural, and they keep talking about my lip, that my braids are fake, that I am not pretty, I am ugly. Anything I say is a problem"

(Semi-structured interview, Kyra).

Following are Kyra's writings about the worse thing about school for her:

Table 4 - Racism described by Kyra.

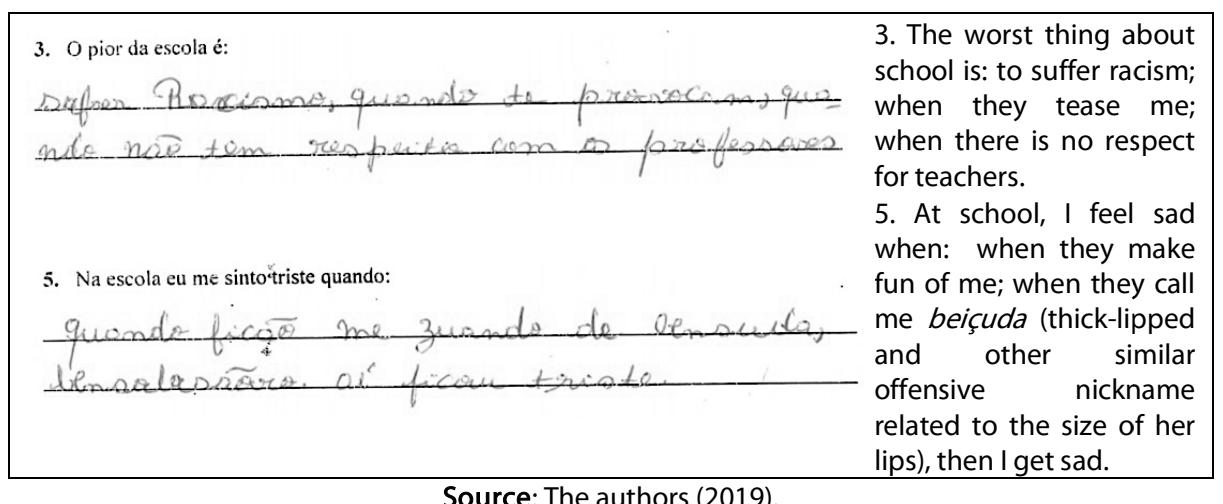

The United Nations International Convention on the Elimination of All Forms of Racial Discrimination (UNITED NATIONS, 1966) adopted in December 1965, defines racial discrimination as

any distinction, exclusion, restriction, or preference based on race, color, descent, or national or ethnic origin which has the purpose or effect of nullifying or impairing the recognition, enjoyment or exercise, on an equal footing, of human rights and fundamental freedoms in the political, economic, social, cultural or any other field of public life. (Article 1) 
LANGFELDT, C. C.; URSIN, M.

The elements described by Kyra, as the size of the lip, the texture of hair and the hairstyle, the nose, among other characteristics, constitute a group of elements due to which black girls and women experience discrimination. "This reflects the dominant beauty paradigm which privileges white/light skin, straight hair, and what are seen to be European facial features. Racist aesthetics is related to institutional racism, in which "the culture, aesthetic standards, and power practices of a particular group become the civilization horizon of society as a whole" (Almeida, 2019, p. 20, own translation).

Chó, Mole, and Sun also experience racism at school, but through racial insults. During the activity collective drawing, Chó talked about how they feel at school, mentioning that "sometimes we are happy, sometimes sad". When asked the reasons for sadness, they mentioned:

\footnotetext{
Mole: Because sometimes they humiliate people here. Camila: How do they humiliate people?

Chó: They keep calling us bald bread (pão careca) all the time, black cockroach (barata preta). For example, Sun (another research participant) they call her black cockroach. They call me negresco. [...] Mole: [...] these things... they happen every day. They take everything out on us.

Mole: They call us imitation apes (macaco de imitação) .... they call blacks as apes (macaco).

(Collective draw activity, Chó and Mole)
}

About the terms mentioned, the term pão careca is a racist, pejorative and offensive expression to offend people who have frizzy hair. The expression is related to the expressions 'bad hair' and 'hard hair'. The black cockroach (barata preta), Guimarães (2000) observes that the cockroach when used as a racial insult is used to call black people dirty. Also, the cockroach, as a racial insult, was observed by Guimarães (2000) as a term that refers to "simultaneously to dirt and the female genitalia" (GUIMARÃES, 2000, note 6.). Thus, the cockroach as an insult it is used to offend black woman. Negresco is the name of a chocolate cookie. So, when the Chó classmates call her negresco, it seems that they are saying that she is so black as the cookie. Regarding ape (macaco), as a racist insult it originated during the colonization period in which colonizers considered that Africans and native populations were inferior and uncivilized races, closer to apes than to humans (BRADLEY, 2013). On the other hand, the expression imitation apes (macaco de imitação) refers to the expression copycat, and it describes a person without initiative or someone who copies the behavior of others (SILVA, 2020).

ALMEIDA (2019) advocates that all kinds of racism is structural, and that racism cannot be understood only as prejudice or racial discrimination. However, racism operate at different levels. The majority of students at both schools are mixed race and black. However, Angolan and Congolese children have darker skins. Also, they have different phenotypes traces than the Brazilian black students, and their origin is also visible through their hairstyles. Kyra, for example, has long braids, which are distinctive in that context. She thinks her classmates are jealous of her hair. However, more than jealousy, her braids make visible her Congolese identity. Beyond discrimination related to identity, which is explored in the next topic, it is important to highlight that Brazil is a 
country where a structural racism prevails (ALMEIDA, 2019), and when immigrants and refugees come to Brazil, they start to experience racism as well.

Margaret Hunter (2007) affirms that discrimination works first in relation to race, and secondly regarding color. The first discrimination/exclusion criterium is race (as Black, African, Asian, Latino, etc.). Secondly, it is the skin color that operates (darker skin and lighter skin). The level of discrimination rises with the intensity of the skin tone. Although all black people suffer discrimination, those with darker skin suffer even more. This process, which is called colorism (HUNTER, 2007), can be described as "a system that privileges the light-skinned over darker-skinned peoples within a community of color" (Hunter, 2007, p. 237). Thus, even within the same group, colorism privileges lightskinners overs dark-skinners. It is "racism inside racism" (Hunter, 2007, p. 237).

The Brazilian population that lives in this neighborhood also suffers different kinds and levels of racism. In structural terms, racism results in poor public services, low access to rights, and limited social freedoms. In addition, in a strong social stratified society, the population that occupy this neighborhood is in a subaltern condition in relation to other social classes, which are also other racial groups. The Angolan and Congolese populations are in a similar situation. However, beyond the restrictions of this social space, they also have darker skin which makes them more vulnerable to racial discrimination, and because of their immigrant and refugee status, they also suffer ethnic discrimination. Following, the next section explores how, in addition to racism, xenophobia is also a part of children school experiences.

\section{XENOPHOBIA}

In the activity collective drawing, children were asked to draw the school in pairs and to write some words about the school around it. Four children participated in this activity, two from Brazil and two from Congo. The follow dialogue happened during the activity:

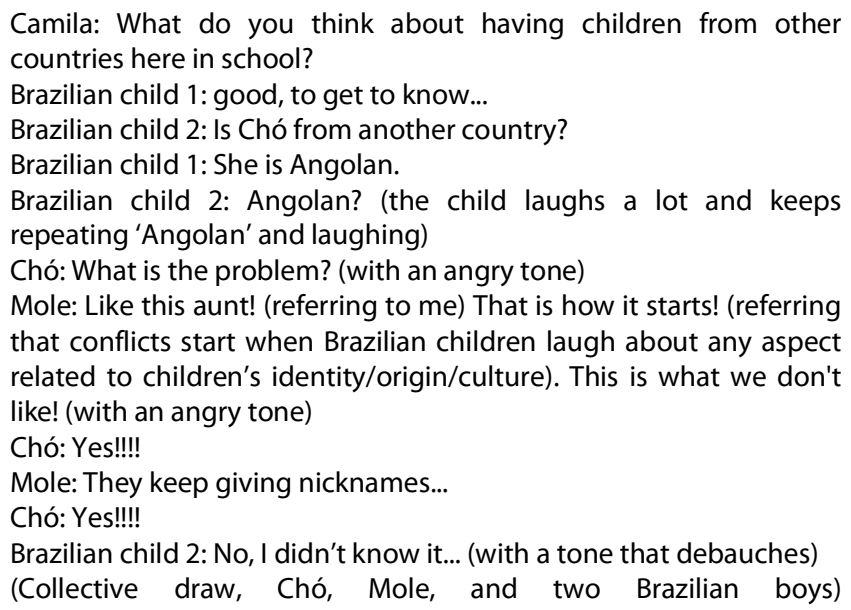


LANGFELDT, C. C.; URSIN, M.

This conversation was very tense. Chó and Mole got very angry when one of the Brazilians started to laugh at the word Angolan. Similarly, Kyra mentioned that "they always talk about Angolan, but I don't understand why" (Semi-structured interview, Kyra). The practice of calling others 'Angolan' was described by one teacher, at this same school, interviewed by the research group from the Faculty of Education of Baixada Fluminense (FEBF/UERJ). This teacher, when talking about her experience with a female pupil from Congo, affirmed:

Here we have many black students, but the students from Congo are different. The skin tone is darker, they stand out with their hairstyles. So, we look and see that there is not a Brazilian child, and children also see it. So, they started to call her Angolan at the first moment. Some students were saying Angolan, Angola, Angolan. At the moment she called me and said that she was upset because they were calling her Angolan. I started to talk with the class about it, to understand why they were calling her Angolan. One of the students said, "ah, she looks like the Angolan from the hill". So, there is someone where they live who they call Angolan. But why Angolan? What means to be Angolan? "Ah, it is because she has the same skin color as him" [...]. Many students here have the habit to call black people as Angolans. (Teacher interviewed by the FEBF/UERJ group, 2018/2019)

This quote reinforces what was discussed in the previous section about how the skin color and the hairstyle of Congolese children distinguish them from the Brazilian black children. Also, the quote shows that Angolan, more than a word that describes someone from Angola, has a different connotation. Another teacher, interviewed by the same group, affirmed that "this 'your Angolan' is an offensive thing, using the condition of Angolan or African as a curse" (Teacher interviewed by the FEBF/UERJ group, 2018/2019).

According to Caritas Rio de Janeiro, refugees from African countries suffer "a triple prejudice: besides being a refugee, being black, and African" (FELIX, 2019, para. 17, own translation). This is not different in the school context. During the group interview with the pedagogical adviser, one of them told us that the first time she met a refugee student in school was through a conflict situation. This school offers the final stages of youth and adult education (EJA) and the conflict was between students around 17 years old. According to her:

the head of the school called me because it was a fight on the second floor, and I went there to see [...] the conflict was between the old students and a couple from Congo [...]. They were using very strong phrases, like: "These apes come from there to disturb us here", "he wants to take our jobs" [...]. It was not just a common youth conflict. It had a bit of xenophobia in it, you know? Because the great majority of students in that class, and the great majority in the school, is black. So, it was a question of, besides being black, they were from another place.

(Group interview, pedagogical advisor) 
The above quote shows a common xenophobic idea which reveals a fear that outsiders will undermine opportunities of the local population. The publication 'International Migration, Racism, Discrimination and Xenophobia' (Inter-Agency, 2001) describes xenophobia as "the intense dislike or fear of strangers or people from other countries, [...] an attitudinal orientation of hostility against non-natives in a given population" (INTER-AGENCY, 2001, p. 2). Further, "xenophobia describes attitudes, prejudices and behavior that reject, exclude and often vilify persons, based on the perception that they are outsiders or foreigners to the community, society or nation identity" (Inter-Agency, 2001, p. 2). The situation described by the pedagogical advisor shows how the Brazilian population in this area fell threatened by the outsiders. In a context where the social conditions of the excluded Brazilian population are already very reduced, an outsider with more abilities can potentialize the fear of unemployment. This can be true in the context of this study. The principal of one of the schools, which was interviewed by the FEBF/UERJ research group, affirmed that the refugee children started to arrive at that school around 2014/2015 and during that period, the school noticed that children were being segregated. The school investigated it and found out that it was the local community that was motivating the discrimination against them. The problems at school were coming from the community around (FEBF/UERJ group, $2018 / 2019$ ) that was afraid that immigrants and refugees would take their opportunities.

Beyond this kind of discrimination, a pedagogical adviser mentioned that when a refugee child first starts school, they are always very shy "because many of them suffer prejudice from the classmates" (Group interview, pedagogical advisor). They noticed that refugee children have resistance to communicate because when they talk, other children will notice they are different. So, "they always try to omit the peculiar traits of their nationality [...]. Because these marks can initially sound negative when the classmates evaluate" (Group interview, pedagogical advisor). In addition, all the six young participants of this study, when asked by us if the school should have any special program for immigrant and refugee children, answered no. Both Kyra and Chó affirmed that a special program could potentialize discriminatory practices. In other words, they are afraid to show they are different.

In addition to the topics thus far explored, Angolan and Congolese children also described experiences involving peer coercion. The next topic shows how it happens.

\section{PeER COERCION}

According to Chó and Mole, they suffer many threats at school, being the threat a part of their daily lives at school. In an informal conversation with Mole and a Brazilian boy, they shared a history about an incident with a classmate:

Mole: The bad thing about coming to school is to be afraid that other students will bring something to kill you. Because they say, "you will see, I will kill you, I will bring a knife from home!", they say such things.

Brazilian boy: The teacher said she was going to call Mole's father and Carlos (pseudonym)' father to talk because Carlos threatened 
LANGFELDT, C. C.; URSIN, M.

me and Mole. Then, after she said that, Carlos came and said "call my father, call him. My father has already caught two at work with a knife" ${ }^{\prime \prime}$.

Mole: Yes. He said that.

Brazilian boy: He said that his father has already caught two at work with the knife. He said his father was going to come and get us with the knife. (Informal talk with Mole and another Brazilian boy)

FOSCO; FRANK e DISHION (2012) describe the threat as a type of peer coercion to drive someone away. This kind of coercion needs to be understood, especially in this context, as "a result of the complex interplay between individuals and their broader social environment" (ESPELAGE; SWEARER, 2009, p. 333). Beyond individual characteristics, peer relationships, family issues, among other individual elements, "the characteristics of the community in which children live and go to school also have direct impact and indirect influences on these behaviors" (ESPELAGE; SWEARER, 2009, p. 343). This is very clear in this context. Children live in a space dominated by different levels of violence demarcating social positions. According to the quote above, this boy uses his father as a way to impose himself. Similarly, the pedagogical advisers, when asked what children have in common with each other, discussed among themselves:

A: too much contact with violence...

B: ... a daily routine where violence is present all the time. Not only armed violence, which is already very serious but also this very aggressive relationship between peers. They do it to impose themselves... we see this a lot here. Every time there is a little problem, there is aggression. One hit the other, the other slapped back. I believe they build themselves, as a subject, overlapping in violence. So, I speak louder because the other one is shouting at me. A: So, I have to hit...

B: ... if one hits me, I have to fight back, because if I do not do it, I invalidate myself at this space.

A: And I do not conquer my space here either. Because, for them, the notion of conquering space is very tied to the reality they live in. What is the reality of the slum traffic? It is a conquest, a search for territory, a dispute over territory. It is a conflict over violence. They do not dispute with talk, with democracy. They use violence. Whoever has more armed power has more hierarchical power within the favela. So, children experience this, and it is impossible to not reproduce it. Because if they live in this social place, they will bring it to school [...] what you see in their interpersonal relationships is violence, all the time.

B: Yeah, whether it is verbal or physical, right? So, this question of deprivation of material resources, the precariousness of public services, racism. I think these things go through everyone, all our students.

A: They end up reproducing what they live.

(Group interview, pedagogical advisors)

This quote shows that the way violence happens in school is similar to the way it happens outside in the favelas that surround this area. Moreover, the pedagogical 
advisers recognize that violence in this context is not only a reflection of the local violence experienced in this particular neighborhood. What happens in this particular context is a result of a wider context where social inequalities, territorial segregation, structural racism, and deprivation of rights prevails, making all children victims of it.

\section{FINAL REFLECTION}

The empirical material presented in this article demonstrated that among the difficulties that Angolan and Congolese children experience in school, peer relationships are one of the main challenges faced by most of them. Children experience bullying, racism, xenophobia, and peer coercion in both schools. Bullying is one of the main problems faced by native Brazilian children in school as well. However, the bullying targeting Angolan and Congolese children is connected with their racial and ethnic characteristics, thus the victimization assumes the form of racial and ethnic discrimination.

The child participants live in a situation of poverty and are situated in a context of high social vulnerability and unsafety. The challenges reported by them show how major exclusionary practices operate in their daily lives. These patterns, more than individual insults, indicate systemic marginalization of the people with specific traits, origins, and ethnic characteristics. In this way "intersectionality calls attention to social identities that are consistently treated as marginal or invisible [...] and, points to the complex nature of power, undermining all reductive theories of oppression" (HARRIS; LEONARDO, 2018, p. 5). Children's experiences cannot be reduced only to bullying, coercion, racism, and xenophobia. The overlapping of these categories of oppression creates a much heavier discrimination experience, which is experienced uniquely by the black immigrants and refugees with African background. Analyzing the experiences of the group of children from Brazil and the group from Angola/Congo, it is possible to affirm that the conflicts described here, more than individual insults, are structural subordination constrains.

To conclude, we highlight that immigrant and refugee children can face several challenges in school. In this study, the participants did not present difficulties concerning their learning process. However, international studies on the education of immigrant and refugee children describe many difficulties children can face, such as the language barriers, the adaptation to the school norms, and the methodology, among many others. For any kind of education program for immigrant and refugee children it is crucial to keep in mind that children are vulnerable to discrimination from their peers.

So, it is necessary to be identify such behaviors and dynamics. Immigrant and refugee children must have their educational needs provided for by the school, and at the same time it is also important to not exclude the Brazilian students from it, as it can create a feeling of unfairness and generate more discrimination. In addition, to combat discrimination against immigrants and refugees' children with African backgrounds is necessary to handle with the systemic discrimination present in the structure of the Brazilian society, which tremendously affect the Brazilian black children, especially in socially segregated areas at the Rio de Janeiro Metropolitan Region. 
LANGFELDT, C. C.; URSIN, M.

Artigo recebido em: 01/04/2021

Aprovado para publicação em: 28/05/2021

ENTRE O BULLYING E OUTRAS VIOLÊNCIAS: EXPERIÊNCIAS DE CRIANÇAS IMIGRANTES E REFUGIADAS NO ENSINO FUNDAMENTAL EM DUQUE DE CAXIAS (RJ)

RESUMO: Este artigo explora os principais desafios enfrentados por um pequeno grupo de crianças da Angola e da República Dominicana do Congo em duas escolas de ensino fundamental em um bairro de Duque de Caxias, município parte da Região Metropolitana do Rio de Janeiro. $O$ artigo baseia-se em um estudo qualitativo multimetodológico com crianças e membros da comunidade. O material empírico mostra que a maior parte das crianças que participaram deste estudo sofrem diferentes tipos de assédio entre pares na escola. Além disso, as crianças experienciam uma tripla forma de discriminação na escola, primeiramente, por serem negras; em segundo lugar por serem estrangeiras; e em terceiro lugar por serem africanas.

PALAVRAS-CHAVE: Pesquisa com Crianças. Educação Formal. Crianças Imigrantes e Refugiadas. Educação para Refugiados.

ENTRE EL ACOSO ESCOLAR Y OTROS TIPOS DE VIOLENCIA: EXPLORANDO LAS EXPERIENCIAS DE NIÑOS INMIGRANTES Y REFUGIADOS EN LA ESCUELA PRIMARIA EN DUQUE DE CAXIAS (RJ)

RESUMEN: Este artículo explora los principales desafíos enfrentados por un pequeño grupo de niños naturales de Angola y de la República Democrática del Congo en dos escuelas primarias de Duque de Caxias, municipio perteneciente al area metropolitana de Rio de Janeiro. El artículo se basa en un estudio cualitativo multimetódico llevado a cabo con niños y los miembros de sus comunidades. Los resultados muestran que la mayoría de los participantes angoleños y congoleños de este estudio sufre diversas formas de acoso por parte de sus compañeros; en concreto por su raza, etnicidad, y origen.

PALABRAS CLAVE: Investigación con Niños. Educación Formal. Niños Inmigrantes y Refugiados. Educación de los Refugiados.

\section{NOTES}

1 - Immigrant and refugee children are included in the so-called children on the move group. The term is an umbrella definition for people below the age of 18 years old that have moved from their original residence. It encompasses children internally displaced, asylum-seekers and refugee children, stateless children, migrant children, trafficked children, and child soldiers (UNHCR, 2016). 2 - The study "School experiences of children on the move: voices of immigrant and refugee children in primary education in the periphery of Rio de Janeiro, Brazil" was supervised by the professors Marit Ursin and Ida Marie Lyså from the Norwegian University of Science and Technology (NTNU), and co-supervised by professor Irene Rizzini from the Pontifical Catholic 
University of Rio de Janeiro (PUC-Rio).

3 - Most of them are from the Waraos ethnicity, which is the second largest indigenous group in Venezuela (MONTENEGRO, 2019).

4 - CONSELHO ESTADUAL DE EDUCAÇÃO DE SÃO PAULO (1997); (SECRETARIA DE EDUCAÇÃO DE SÃO PAULO, 1995; 1998),

5 - CONSELHO ESTADUAL DE EDUCAÇÃO DO PARANÁ (2001)

6 - CONSELHO DE EDUCAÇÃO DO DISTRITO FEDERAL (2002).

7 - Xitu attend school through the modality EJA elementary school.

8 - This group studies the integration of migrant and refugee children at a public school in Duque de Caxias. The project "The integration of migrant and refugee children at the public school of Duque de Caxias (RJ)" is coordinated by professors Leila Carvalho de Mendes and Kelly Russo from FEBF/UERJ. The group has recently published two articles about this project (MENDES; RUSSO; BARROS, 2020; RUSSO; MENDES; BORRI-ANADON, 2020).

9 - It means that the father of this child has already stabbed two people during his work, or at his workplace. In Portuguese: "já pegou dois no trabalho com uma faca".

\section{REFERENCES}

ABEBE, T. Multiple methods, complex dilemmas: negotiating socio-ethical spaces in participatory research with disadvantaged children. Children's geographies, ano 7, n. 4, p. 451-465, 2009.

ALMEIDA, S. Racismo estrutural [Structural racism]. São Paulo: Jandaíra, 2019.

BRADLEY, J. The ape insult: a short history of a racist idea. The Conversation, Melbourne, May 30 2013. Disponível em: https://theconversation.com/the-ape-insult-a-shorthistory-of-a-racist-idea-14808. Acesso em: 26 set. 2020.

BRASIL. Lei n॰ 8.069, de 13 de julho de 1990. Dispõe sobre o Estatuto da Criança e do Adolescente e dá outras providências [Law no. 8069, July 13, 1990. Provides for the Statute of Children and Adolescents and provides other measures]. Brasil, 1990. Disponível em: http://www.planalto.gov.br/ccivil_03/leis/l8069.htm. Acesso em 15 set. 2020.

BRASIL. Lei n 9.394, de 20 de dezembro de 1996. Estabelece as diretrizes e bases da educação nacional [Law no. 9394, 20 December 1996. Establishes the guidelines and bases of national education]. Brasil, 1996. Disponível em: http://www.planalto.gov.br/ccivil_03/leis/19394.htm. Acesso em: 15 set. 2020.

BRASIL. Lei no 13.005, de 25 de junho de 2014. Aprova o Plano Nacional de Educação - PNE e dá outras providências [Law no. 13.005, 24 June 2014. Approves the National Education Plan - PNE and takes other measures]. Brasil, 2014. Disponível em: http://www.planalto.gov.br/ccivil_03/ato20112014/2014/lei/l13005.htm. Acesso em: 15 set. 2020. 
LANGFELDT, C. C.; URSIN, M.

BRASIL. Lei no 13.445, de 24 de maio de 2017. Institui a lei de migração [Law no. 13445, 24 May 2017. Institutes the migration law]. Brasil, 2017. Disponível em: http://www.planalto.gov.br/ccivil_03/_ato2015-2018/2017/lei/l13445.htm. Acesso em: 15 set. 2020.

BROWN, C. S. The educational, psychological, and social impact of discrimination on the immigrant child. Migration Policy Institute: Washington DC, 2015. Relatório. Disponível em: https://www.issuelab.org/resources/22382/22382.pdf. Acesso em 15 set. 2020.

CASA FLUMINENSE. Mapa da desigualdade [Map of inequality]. Rio de Janeiro, 2010. Relatório. Disponível em: https://casafluminense.org.br/mapa-da-desigualdade/. Acesso em 18 abr. 2020.

CONARE. Refúgio em números $4^{\mathrm{a}}$ edição [Refuge in numbers 4th edition]. Ministério da Justiça e Segurança Pública, Brasil, 2019. Disponível em: https://www.acnur.org/portugues/wp-content/uploads/2019/07/Refugio-emnúmeros_versão-23-de-julho-002.pdf Acesso em: 18 abril 2020.

CONSELHO DE EDUCAÇÃO DO DISTRITO FEDERAL. Parecer n CEB 18/2002. Consulta sobre equivalência de estudos em cursos realizados no exterior [Opinion no. CEB $18 / 2002$. Consultation on equivalence of studies in courses taken abroad]. Brasilia, 2002. Disponível em: http://portal.mec.gov.br/cne/arquivos/pdf/CEB018_2002.pdf. Acesso em 15 set. 2020.

CONSELHO ESTADUAL DE EDUCAÇÃO DE SÃO PAULO. Deliberação n 16/97. Dispõe sobre a matrícula de aluno estrangeiro no ensino fundamental e médio do sistema de ensino do Estado de São Paulo [Resolution no. 16/97. Provides for the registration of foreign students in elementary and high school in the education system of the State of São Paulo]. São Paulo, 1997. Disponível em:

http://siau.edunet.sp.gov.br/ItemLise/arquivos/notas/delcee16_97(parcee445_97).htm.

CONSELHO ESTADUAL DE EDUCAÇÃO DO PARANÁ. Deliberação n 09/01 [Resolution no. 09/01]. Paraná, 2001. Disponível em:

http://celepar7cta.pr.gov.br/seed/deliberacoes.nsf/bb7cccb67074826503256f4800653a 4b/d028154429fbb40203256ae9004d7094/\$FILE/_j8himogb2clp631u6dsg30e9d68o30c 8_.pdf. Acesso em: 1 abril 2021.

CORREA-VELEZ, I.; GIFFORD, S. M.; BARNETT, A. G. Longing to belong: Social inclusion and wellbeing among youth with refugee backgrounds in the first three years in Melbourne, Australia. Social science \& medicine, ano 71, n. 8, p. 1399-1408, 2010.

DPU. Missão Pacaraima: $3^{\circ}$ informativo de atuação [Mission Pacaraima: 3rd activity report]. Relatório, 2020. 
DRYDEN-PETERSON, S. The educational experiences of refugee children in countries of first asylum. National Center on immigrant integration policy. Canada: British Columbia Teachers' Federation, 2015. Disponível em:

https://www.migrationpolicy.org/sites/default/files/publications/FCD_Dryen-PetersonFINALWEB.pdf Acesso em: 1 abril 2021.

DRYDEN-PETERSON, S. Refugee education in countries of first asylum: Breaking open the black box of pre-resettlement experiences. Theory and research in education, 14, n. 2, p. 131-148, 2016.

ENNEW ET AL. The Right to Be Properly Researched. How to Do Rights-Based Scientific Research with Children: A Set of Ten Manuals for Field Researchers. Bangkok: Black on White Publications, Knowing Children, 2009.

ENNEW, J.; PLATEAU, D. P. How to research the physical and emotional punishment of children. Bangkok: Save the Children, 2004.

ESPELAGE, D. L.; SWEARER, S. M. A social-ecological model for bullying prevention and intervention. In: JIMERSON, S. R.;SWEARER, S. M., et al (Ed.). Handbook of bullying in schools: An international perspective, London: Routledge, 2009, p. 61-72.

FEBF/UERJ group. Dossiê professoras. Transcrição das entrevistas com as professoras sobre refúgio. Projeto: A integração de crianças migrantes e refugiadas na escola pública de Duque de Caxias (RJ). Rio de Janeiro, 2018/2019, não publicado.

FELIX, D. Refugiados africanos falam sobre experiências de racismo no Brasil: "Dói muito" [African refugees talk about experiences of racism in Brazil: "It hurts a lot"]. Programa de Atendimento a Refugiados e Solicitante de Refúgio Rio de Janeiro, 2019. Disponível em: http://www.caritas-ri.org.br/refugiados-africanos-falam-sobreexperiencias-de-racismo-no-brasil.html. Acesso em: 4 set. 2020.

FOSCO, G. M.; FRANK, J. L.; DISHION, T. J. Coercion and contagion in family and school environments: Implications for educating and socializing youth. In: JIMERSON, S.;NICKERSON, A., et al (Ed.). Handbook of school violence and school safety: International research and practice. New York: Routledge, 2012. p. 69-80.

GRAHAM, H. R.; MINHAS, R. S.; PAXTON, G. Learning problems in children of refugee background: A systematic review. Pediatrics, 137, n. 6, p. e20153994, 2016.

GUIMARÃES, A. S. A. O insulto racial: as ofensas verbais registradas em queixas de discriminação [Complaints filed against discrimination]. Estudos Afro-Asiáticos. Rio de Janeito: n. 38, p. 1-15, 2000. 
LANGFELDT, C. C.; URSIN, M.

HARRIS, A.; LEONARDO, Z. Intersectionality, race-gender subordination, and education. Review of Research in Education, 42, n. 1, p. 1-27, 2018.

HUNTER, M. The persistent problem of colorism: Skin tone, status, and inequality. Sociology compass, 1, n. 1, p. 237-254, 2007.

INTER-AGENCY. International migration, racism, discrimination and xenophobia. Relatório, 2001.Disponível em: https://www.refworld.org/docid/49353b4d2.html. Acesso em 15 set. 2020.

JAMES, A.; JAMES, A. Key concepts in childhood studies. $2^{\text {nd }}$ ediction. United Kingdom: Sage, 2012.

JAMES, A.; JENKS, C.; PROUT, A. Theorizing childhood. New York: Polity, 1998.

MAYALL, B. Conversations with children: Working with generational issues. In: CHRISTENSEN, P. e JAMES, A. (Ed.). Research with children: perspectives and practices. New York: Routledge, 2005. cap. 5, p. 126-141.

MENDES, L.; RUSSO, K.; BARROS, K. D. Entre hospitalidade e hostilidade: famílias em situação de imigração na rede pública de educação brasileira [Between hospitality and hostility families in immigration situation in the brazilian public education network]. Dialogia, n. 35, 2020, p. 200-213.

MINISTÉRIO PÚBLICO FEDERAL. Recomendação n 10/2017 [Recommendation no. 10/2017]. Brasil, 2017. Disponível em: http://www.mpf.mp.br/rr/sala-deimprensa/docs/recomendacao-no-10. Acesso em: 1 abril 2021.

MONTENEGRO, C. A difícil vida das crianças e jovens venezuelanos no norte do Brasil, em meio a crise de refugiados [The difficult life of Venezuelan children and youth in northern Brazil in the midst of the refugee crisis]. BBC News Brazil, 2019. Disponivel em: https://www.bbc.com/portuguese/internacional-48692656. Acesso em: 1 abril 2021.

MORROW, V. Practical ethics in social research with children and families in young lives: A longitudinal study of childhood poverty in Ethiopia, Andhra Pradesh (India), Peru and Vietnam. Methodological Innovations Online, 8, n. 2, 2013, p. 21-35.

OLWEUS, D. Introduction: Peer harassment: A critical analysis and some important issues. In: JUVONEN, J. e GRAHAM, S. (Ed.). Peer harassment in school: The plight of the vulnerable and victimized. New York, London: The Guilford Press, 2001, p. 3-20.

PEGUERO, A. A. Victimizing the children of immigrants: Latino and Asian American student victimization. Youth \& Society, 41, n. 2, 2009, p. 186-208.

PUNCH, S. Cross-world and cross-disciplinary dialogue: A more integrated, global approach to childhood studies. Global Studies of Childhood, 6, n. 3, 2016, p. 352-364. 
RUSSO, K.; MENDES, L.; BORRI-ANADON, C. Crianças em situação de imigração na escola pública: percepções de docentes. Cadernos de Pesquisa, 50, n. 175, p. 256-272, 2020.

GOVERNO DO ESTADO DE SÃO PAULO. Documento Orientador CGEB/NINC, Estudantes imigrantes: acolhimento [Imigrant students: reception]. CGEB, DEGEB, CAESP, NINC. São Paulo. 2018a. Disponível em:

https://www.educacao.sp.gov.br/wp-content/uploads/2018/12/ACOLHIMENTO_FINALcompressed.pdf Acesso em: 1 abril de 2021.

GOVERNO DO ESTADO DE SÃO PAULO. Documento Orientador CGEB/NINC, Estudantes imigrantes: Matrículas e certificados [Immigrant students: enrollments and certificates]. CGEB, DEGEB, CAESP, NINC. São Paulo. 2018b. Disponível em: https://www.educacao.sp.gov.br/wp-content/uploads/2018/12/MATRíCULA_FINALcompressed.pdf. Acesso em: 1 abril 2021.

SECRETARIA DE EDUCAÇÃO DE SÃO PAULO. Resolução no 10, de 2 de fevereiro de 1995. Dispõe sobre matrícula de aluno estrangeiro na rede estadual de ensino fundamental e médio [Resolution no. 10, 2 February 1995. Provides for foreign student enrollment in the state network of elementary and high school]. São Paulo, 1995. Disponivel em: http://siau.edunet.sp.gov.br/ItemLise/arquivos/10_1995.htm. Acesso em: 15 set. 2020.

SECRETARIA DE EDUCAÇÃO DE SÃO PAULO. Resolução $n^{\circ} 20$, de 5 de fevereiro de 1998. Dispõe sobre a operacionalização da reclassificação de alunos das escolas da rede estadual [Resolution no. 20, 5 February 1998. Provides for the operationalization of the reclassification of students from state schools]. São Paulo, 1998. Disponível em:

http://siau.edunet.sp.gov.br/ItemLise/arquivos/20_1998.htm. Acesso em: 15 set. 2020.

SIDHU, R.; TAYLOR, S.; CHRISTIE, P. Schooling and Refugees: engaging with the complex trajectories of globalisation. Global studies of Childhood, 1, n. 2, 2011, p. 92-103.

SILVA, O. Qual a origem e significado da expressão "macaco de imitação"? [What is the origin and meaning of the expression "imitation ape?"]. 2020. Disponivel em: https://www.mitologia.pt/qual-a-origem-e-significado-da-279506. Acesso em: 26 set. 2020.

UNESCO. Unpacking Sustainable Development Goal 4: Education 2030; guide. 2016. Disponível em: https://unesdoc.unesco.org/ark:/48223/pf0000246300 Acesso em: 1 abril de 2020.

UNESCO. Global education monitoring report, 2019: Migration, displacement and education: building bridges, not walls. 2019. Disponível em:

https://unesdoc.unesco.org/ark:/48223/pf0000265866 Acesso em: 1 abril 2020. 
LANGFELDT, C. C.; URSIN, M.

UNHCR. Refugee Education 2030. A Strategy for Refugee Inclusion. 2019. Disponível em: https://data2.unhcr.org/en/documents/details/71213 Acesso em: 1 abril 2021.

UNICEF. Action for Refugee Children. 2019. Disponível em:

https://www.unicef.org/media/83566/file/Good-practices-that-bring-the-GlobalRefugee-Compact-to-Life.pdf Acesso em: 1 abril 2020.

UNICEF. Crise migratória venezuelana no Brasil [Venezuelan migratory crisis in Brazil]. 2020. Disponível em: https://www.unicef.org/brazil/crise-migratoriavenezuelana-no-brasil. Acesso em: 26 april 2020.

UNITED NATIONS. International Convention on the Elimination of All Forms of Racial Discrimination, $1966 . \quad$ Disponível em: https://www.ohchr.org/en/professionalinterest/pages/cerd.aspx Acesso em: 1 abril 2021.

Camila Caldeira Langfeldt: Master's degree in childhood studies from the Norwegian University of Science and Technology (NTNU) and a bachelor's degree in Pedagogy from the Federal University of Paraná (UFPR). Researcher at the Worldviews research group at the Norwegian University of Science and Technology and pedagogue at the Norwegian foundation Kirkens Bymisjon Trondheim.

Orcid: https://orcid.org/0000-0001-6391-9258

E-mail: camilalangfeldt@hotmail.com

MARIT URSIN: Associate professor in interdisciplinary Childhood Studies at Norwegian University of Science and Technology. She has executed a longitudinal study with youns people on the verge of adulthood on the street in urban Brazil as part of her MA in anthropology and $\mathrm{PhD}$ in sociology. She has also worked with children in institutional settings in Mexico, studied the impact of the drug trade in youth's everyday lives in Brazil, and explored children's political rights in Norway.

Orcid: https://orcid.org/0000-0002-7529-5259

E-mail: marit.ursin@ntnu.no

Este periódico utiliza a licença Creative Commons Attribution 3.0, para periódicos de acesso aberto (Open Archives Initiative - OAI). 